\title{
Mexican Samples, Latino DNA: The Trajectory of a National Genome in Transnational Science
}

\author{
EMILY VASQUEZ \\ COLUMBIA UNIVERSITY \\ VIVETTE GARCÍA-DEISTER ${ }^{2}$ \\ UNIVERSIDAD NACIONAL AUTÓNOMA DE MÉXICO
}

\begin{abstract}
Experts have widely promoted developing country investment in national genome projects in order to ensure their inclusion in medical genomic advances, to protect their genomes from foreign exploitation, and to foster their participation in a future genomics-based bioeconomy. In this context, the Mexican federal government's investments to establish the National Institute of Genomic Medicine in 2004, that institute's subsequent efforts to map the "Mexican genome" between 2004 and 2009, and the passage of legislation in 2008 to protect Mexico's "genomic sovereignty" drew attention as the most comprehensive national genomics program among the world's emerging economies. Given the prominence of Mexico's decision to pursue its "national genome" and to understand how this approach to science policy has unfolded with time, we track major developments in the field of genomic medicine in Mexico and the trajectory of the "Mexican genome" over the last decade. Rather than the nation-state bound "Mexican genome," we show that flexibility and ambiguity with regard to genomic identity has been instrumental amid the increasingly transnational and public-private nature of this scientific field. Over the last decade, Mexican samples have frequently been re-branded as the source of flexible, panethnic "Latino" or "Latin American" DNA.
\end{abstract}

\section{Keywords}

national genomes; genomic sovereignty; panethnicity; ambiguity; bioeconomy; Latin America

\section{Introduction}

By the late 1990s, amidst mounting excitement about the scientific, medical, and economic potential set to be un-locked with the mapping of the human genome, countries across the globe began to view their citizens' DNA as a potential national resource. Countries including France,

. Emily Vasquez, Email: eev2105@cumc.columbia.edu

2Vivette García-Deister, Email: vivettegarcia@ciencias.unam.mx

Copyright (C) 2019 (Emily Vasquez and Vivette García-Deister). Licensed under the Creative Commons Attribution Non-commercial No Derivatives (by-nc-nd). Available at estsjournal.org. 
Iceland, the United Kingdom, and China, invested in national genomic initiatives, built up biobanking infrastructure, and began mapping and analyzing "national genomes," driven by the possibility of gains in health through new discoveries and by the promise of economic growth with their uptake in the making and selling of pharmaceuticals, diagnostics, and other technologies (Reardon 2017; Fortun 2008; Busby and Martin 2006; Rabinow 1999; Pálsson and Rabinow 1999; Sung 2010; Burton 2018). In developing countries, including Mexico, India, and Thailand, proponents called for research focused on each nation's genome, citing an additional set of motives (Benjamin 2009; Séguin and Hardy 2008; Jiménez Sanchez 2003b; Jiménez Sanchez et al. 2008). Recognizing a legacy of neglect by northern pharmaceutical companies of the diseases most heavily burdening low- and middle-income countries, they argued that developing nations should invest in genomics to ensure that the particular needs of their populations would be met in the "genomic revolution." Further, they expressed the need to protect this national resource from foreign exploitation-a new form of bioprospecting. Proponents also warned that the failure of developing nations to participate in emergent genomics-based sectors of the bioeconomy might cement these countries' economic fates as peripheral to increasingly techbased global markets.

In this context, technoscientific entities like the "Mexican genome" and the "Chinese genome" emerged as the newest iteration of diverse signifiers applied by genetic and genomic scientists to differentiate human groups-this time centering assumptions about the existence of biological similarity within populations bound by a political territory. As Benjamin (2009) has noted, such "national genomes" have not necessarily carried claims of national genetic purity, but have often alluded to the idea that a unique range of genetic mixture-a particular kind of heterogeneity-could be identified within a country's borders. Assemblages of biological, geographic, political, and cultural knowledge (Hinterberger and Porter 2015), these "national genomes" emerged at the intersection of molecular-biological advances, local understandings of difference, and ambitious promises about the future value of genomic knowledge. Mexico's efforts, in particular, to research and protect access to the "Mexican genome," drew international attention as the most comprehensive national genomics program among the world's emerging economies (Séguin et al. 2008; Tekola-Ayele and Rotimi 2015; Hardy et al. 2008).

Given the prominence of Mexico's decision to pursue its "national genome" and to understand how this approach to science policy has unfolded with time, in this paper we track major developments in the field of genomic medicine in Mexico and the trajectory of the "Mexican genome" since 2009. To do so, we draw on interviews with scientists and other key actors in this field, as well as a review of scientific publications and related press coverage. We show that this nationally-tethered (Hinterberger and Porter 2015) genomic identity is much less enduring that it and other "national genomes" might have appeared when proponents initially argued for their importance, especially for developing countries' health and economic futures. Instead, with regard to genomic identity, we show that ambiguity and flexibility (Panofsky and Bliss 2017) have been critical to recent efforts in Mexico to create value from the genome, in both a scientific and commercial sense. Indeed, the "Mexican-ness" of genetic samples collected in Mexico is unstable and frequently de-centered. Mexican samples are today just as often un-bound 
from the nation-state and re-branded, for example, with "Latino" or "Latin American" panethnic identity.

\section{Genomic Identity}

The differentiation of humans into groups or populations is a persistent component of research in genetics and genomics (M'charek 2005; Reardon 2005; Abu El-Haj 2007). It has been widely observed that all human beings are genetically 99.9 percent the same, as US President Bill Clinton reminded the world when he announced the completion of the first draft of the human genome in June of 2000. However, as Fujimura \& Rajagopalan (2011) have noted with regard to medical genetics and genomics, specifically, these fields are "buttressed by a logic of difference" (p. 21), and within them human genetic variation across populations is steadfastly linked to the differential patterning of disease.

But what kind of human group should constitute a population in medical genetics and genomics and what factors shape this decision? In Euro-American genomics, populations have most often been defined along the lines of racial and ethnic groups (Koenig, Soo-Jin Lee, and Richardson 2008; Abu El-Haj 2007; Reardon 2005; Wailoo, Nelson, and Lee 2012; Panofsky and Bliss 2017), despite minimal conceptual coherence around the meaning of race and ethnicity (Fullwiley 2007; Hunt and Megyesi 2008; Soo-Jin Lee et al. 2008). Scholars recognize the epistemic traction of racial logic in the practice of genomic science, where the grip of racial thinking is difficult to escape even when technical justifications are elusive (Fullwiley 2007; Fujimura and Rajagopalan 2011; Reardon 2005). They point to the legacy of struggles for inclusion in health research by groups who identified themselves and sought redress along racial-ethnic lines (Epstein 2009; Tutton 2008). In the United States, these struggles led to legislation requiring the inclusion in health research of socially-salient minority groups-recognized via broad categories including Black or African American, Hispanic/Latino, White, and American Indian. Scholars also report that some scientists express an ethical commitment to medical genomic research conducted on racial and ethnic groups, given health disparities experienced by them (Bliss 2012; Fullwiley 2008). Finally, scholars point to the influence of industry. US pharmaceutical companies and the makers of medical diagnostics have taken interest in and taken up genomics within a ubiquitous race-based commercial marketing (Roberts 2011) and regulatory infrastructure (Kahn 2013; Pollock 2012; Soo-Jin Lee 2005).

Far from a simple issue of nomenclature, with the deployment of racial and ethnic categories in Euro-American genomics, scholars have argued that a "genetic re-inscription of race" (Abu El-Haj 2007) is underway in the scientific and public imagination. The outcome of this, some have warned, has been the re-authorization of race as a biological reality and increasing naturalization of the deep racial inequalities that mark social life and health in the

${ }^{3}$ Genetics involves the study of single genes and their role in the passing of individual characteristics and disease from one generation to the next (i.e. heredity). Genomics, by contrast, addresses all genes and their inter relationships" (WHO 2015) and therefore requires viewing, mapping, and analyzing large portions or all of an organism's DNA. 
United States (Duster 2015, 2005; Fullwiley 2008; Roberts 2011; Montoya 2011; Bliss 2013). But this social science literature also powerfully argues that the categories of human difference that scientists use to differentiate genomes are determined not by the characteristics that scientists discover within them, but rather are deeply structured by how those scientists are positioned and conditioned to see-institutionally, legally, politically, economically, and culturally.

In other settings-particularly in developing regions where the nation has been invoked as a key frame for genomic identity - the legacy of old ways of understanding human difference, issues of inclusion, and access to markets have likewise emerged as key factors driving this approach, although in ways inflected by local particularities. For example, in these contexts nationalized genomic identity has been linked to historically salient ways of understanding difference tied to projects of nation-building and nationalism. This is true in China, for example, where the notion of Zhonghau minzu (roughly translated as Chinese ethnicity), a category proposed by revolutionaries and reformers at the end of the Qing reign to unify all ethnic groups into a single Chinese people, has underpinned the contemporary deployment of the idea of a Chinese genome (Sung 2010). Sung clarifies, however, that minzu or ethnicity has been understood largely as a social phenomenon, "referring to people using the same language, sharing the same culture, living in the same place, and having the same sense of identity" (Sung, 2010, p. 265) since the 1950s, and so its biological connotation within genomic science is new. In Mexico, the ideology of Mestizaje similarly underpinned the emergence of the "Mexican Genome," as we discuss below.

In such contexts, concerns over inclusion (i.e. scientific and medical recognition) are likewise present, articulated primarily by policy-makers and scientists who have called for or justified investments in genomic initiatives as a way by which to ensure future medical attention to developing-country populations (Vasquez and García-Deister 2019). Rather than pointing to long-standing social and health disparities within national contexts (as in the US case), these actors signal disparities on a global scale in access to medical advances, as well as the legacy of the global pharmaceutical industry's neglect of the diseases most heavily burdening these regions (Benjamin 2009; Ecks 2005). Importantly, the alignment of national and genomic identities endorses the notion that a national population is marked by meaningful biologically unity. This can come at the exclusion of minority groups within a nation and can impinge on disputes over territory, belonging, and racial redress, re-making these through the lens of genetic essentialism, where difference was not previously biologized (Benjamin 2009; Sung 2010; Liu 2010; Ventura Santos, Kent, and Gaspar Neto 2014; Kent et al. 2015).

In developing countries, pursuit of national genome initiatives has been driven by prospects for national development. Although genomics has remained a highly speculative enterprise (Fortun 2008; Reardon 2017), proponents have long claimed the alignment of national and genomic identities could spur a local biotech sector with a lucrative market niche. A perspective widely promoted by the Organization for Economic Co-operation and Development (OECD) since the mid-1990s (OECD 2009), this was viewed as a path by which developing countries could gain entry to the global bioeconomy (Petersen and Krisjansen 2015; Birch and Tyfield 2012). Indeed, such expectations have prompted some observers to suggest that countries 
pursing national genomics initiatives came to view their populations as biologically-meaningful "brands" (Tupasela 2017; Benjamin 2009). As we discuss below, in the Mexican case, as elsewhere, the alignment of national and genomic identity took place amid the mobilization of significant public funds for medical genomics and largely in the name of economic development. This was the particular "regime of value" (Appadurai 1986) within which scientific attention to a national genome took root in Mexico.

But would the conditions underpinning the alignment of national and genomic identity endure? While social scientists have attended carefully to the grafting of social categories of human difference onto the genome, shifts in the taxonomies applied to particular groups-the genomic "branding" and then the "re-branding" of populations over time-have received less attention. What truths about the field of genomics-as well as its intersection with race, ethnicity, and nation-might be revealed with the un-raveling or re-branding of genomic identities over time? With Reardon (2017), who has described Scotland's withdrawal from the notion of Scottish DNA, we describe below technological changes and a shifting "regime of value" as key factors that have de-centered the Mexican genome and increased focus on "Latino" and "Latin American" panethnic identity in Mexican medical genomics.

\section{Is There a "Mexican" Genome?}

In 2018, the Mexican airline Aeroméxico sponsored a provocative advertising campaign entitled DNA Discounts." The campaign featured a commercial, in English, that opened with a problem: the US is a key destination for air travel from Mexico, but Mexico is not a key destination for US travelers. The airline poses a question: How can it increase travel from the United States to Mexico when it seems many US citizens are disinterested in their southern neighbor? The commercial continues with a series of interviews with residents of a "typical American town" who state they have no interest in visiting Mexico-indeed, they express considerable disdain for the country. The airline then presents them with the results of a DNA test, offering them discounts on flights to Mexico that match the percentage of their DNA found to be "Mexican." "You are 22\% Mexican...Y You get 22\% off to fly to Mexico," a narrator explains to one interviewee. "That's bullshit," the man responds, incredulously examining his test results. Then, thinking about it, he asks "so what if I want to take my wife?" The video closes with the tagline: "There are no borders within us." This is a unifying sentiment, but when developers launched the video on social media in 2019, the campaign spurred critique in Mexico. On Twitter, one critic wrote: “This campaign doesn't have a leg to stand on, and it's dangerous. 'Mexican DNA' doesn't exist and the idea eliminates Mexico's diversity, ignoring indigenous peoples and afro-descendants" (Vanguardia 2019). Another tweeted "Mexico is a multiethnic, multilingual, multicultural country brought together under a symbolic state. Mexico is NOT a 'race' and with luck it never will be" (Cullell 2019). While the ad passed corporate muster and also garnered applause online, skepticism about the existence and implications of Mexican DNA was immediately evident.

^See https:/ / vimeo.com / 279350887. 
Yet less than 20 years before in Mexico the notion of a Mexican genome and the possibility of tailoring medicine to "Mexicans" at the molecular level garnered a historic endorsement among scientists, politicians, and the public. As the first map of the human genome was announced in the United States, an elite group of Mexican scientists and politicians began a lobby for federal investment in the field of genomic medicine. They successfully persuaded the Mexican Congress to commit an initial investment of US\$120 million to establish a medical genomics research program and to construct a National Institute for Genomic Medicine. The INMEGEN (the institute's acronym) was inaugurated in 2004 as Mexico's newest National Institute of Health, justified by proponents via a kind of social contract with regard to the field's promise for the future. Steeped in nationalistic rhetoric, they claimed that by pursing research focused specifically on the Mexican genome, genomic medicine would revolutionize the prevention and treatment of disease, including the diseases most burdening the Mexican health system and thus the national budget-namely, chronic diseases like diabetes. Further, they argued that foreign researchers and biotech firms could not be trusted to attend to Mexico's particular health burden or ensure the inclusion of knowledge about Mexican bodies in a "genomic future" (Whitmarsh 2008), nor should foreign firms alone benefit from its potential value. Genomic medicine would thus be "made in Mexico, by Mexicans, for Mexicans" (LópezBeltrán, García-Deister, and Rios-Sandoval 2014, 99).

Tethering genomic identity to the nation through the idea of the "Mexican Genome" produced a genomic incarnate of the "Mexican Mestizo" (Lopez-Beltran and García-Deister 2013; López-Beltrán, García-Deister, and Rios-Sandoval 2014). This referenced the long-standing narrative of Mestizaje, originally promoted during Mexico's post-revolutionary era by elite intellectuals to counter European racial mythologies and as a tool for national unification (Wade et al. 2014; Stern 2003). Through the Mestizo, Mexico was imagined as home to a "cosmic race"a unique and superior blend of European, Amerindian, and African people, rooted in but also separate from the country's indigenous people. The re-articulation of the "Mexican Mestizo" in genomic terms offered a widely publicized and powerful scientific endorsement of the Mexican bio-cultural uniqueness espoused by Mestizaje ideology (López-Beltrán, García-Deister, and RiosSandoval 2014; Kent et al. 2015), not separate from but historically entangled with race (Wade et al. 2014). It also offered a familiar way of describing to the public what proponents intended would become the focus of INMEGEN's first flagship project: the elaboration of a map of the Mexican genome. This would take center-stage among the institute's activities over its first administration, resulting in a celebrated 2009 publication (Silva-Zolezzi et al. 2009).

While the INMEGEN pursued the Mexican genome in the lab, its leadership worked to promote the passage of a novel legal framework for the governance of genetic material through amendments to the nation's General Health Law (Secretaría de Gobernación 2008; Benjamin 2009; Hinterberger and Porter 2015; Schwartz-Marín and Méndez 2012). Passed in 2008, these provisions, known as Mexico's policy on genomic sovereignty, made it illegal to transport outside the country human tissue from which DNA may be derived without prior approval from Mexico's Secretary of Health. Moreover, according to these provisions, Mexican genetic material transported to foreign territory could only be utilized for the purposes originally approved. 
In promoting genomic sovereignty, INMEGEN leaders cited the need to protect Mexican genetic material from scientific colonialism-a scenario in which foreign researchers could obtain biological samples in Mexico and then carry them back to foreign institutions for analysis, consolidating elsewhere the intellectual and material profits derived. Their objective was also explicitly to empower Mexican scientists and entrepreneurs within the private sector to develop and market diagnostics and therapeutics tailored specifically to "the Mexican genome" (SerranoPerez-Grovas et al. 2001; Jiménez Sanchez 2003a, 2002; Jiménez Sanchez et al. 2008). Indeed, public investments in genomic medicine were, from the start, intended to foster private enterprise. For this reason, with INMEGEN'S founding in 2004 an office of technological transfer was set up within the institute.

Importantly, the notion of genomic sovereignty has gained traction among scientists and policymakers in several emerging economies around the globe, including in Africa (de Vries, Slabbert, and Pepper 2012; Slabbert and Pepper 2010; Hinterberger and Porter 2015). Writing in Nature Reviews Genetics, international proponents have pointed to Mexico's legislation as exemplary, referring to genomic sovereignty policy as key for developing countries worldwide to "encourage local innovation and participate as equal partners in the global knowledge-based economy" (Séguin and Hardy 2008, 490).

\section{Beyond National Genomics}

The "omics" sciences and specifically genomics are widely understood as the quintessential realm of "Big Data" in the life sciences (Leonelli 2016). By 2010, advances in high-throughput technology for sequencing genomes and in computational tools available for their analysis were driving increasingly large-scale collaborations and the circulation of unprecedented quantities of genetic data around the globe. In this context, early signs of the decentering of the "Mexican genome" as INMEGEN's steadfast focus (as well as challenges to Mexico's genomic sovereignty policy) were evident at INMEGEN, within just months of the publication of its Map of the Mexican Genome.

During ethnographic observation in INMEGEN laboratories from 2010 to 2011, GarcíaDeister (2014) noted the beginnings of this shift toward inter-institutional and international collaboration as the technical imperative for ever-larger data sets intensified. She found that as "Mexican Mestizo" blood samples were processed, their DNA extracted, sequenced, and finally transformed into cloud-stored, digital data, these samples were rendered internationally mobile, skirting genomic sovereignty legislation, which regulated only the circulation of blood samples. Additionally, she found that digitization seemed to unlock these samples from their Mexican identity. "Previously confined to the political margins of the nation," in the context of these early international collaborations, these mobile data were at times "no longer Mexican, but also Latino/a or Hispanic" (García-Deister 2014, 178).

In the years since, the technical imperative for big data sets has continued to intensify and, consequently, this kind of inter-institutional and transnational collaboration has accelerated. Additionally, new key actors have moved to center stage in this arena in Mexico, promoting 
collaboration and the movement of data and knowledge across international borders for other reasons. Most prominently, the Carlos Slim Foundation-based in Mexico City and an increasingly important source of non-state funding for health reform and research-founded the Slim Initiative in Genomic Medicine (SIGMA), propelling Mexican researchers, DNA samples, and data into a transnational circuit of collaboration and exchange.

With a donation surpassing the Mexican state's initial funding to build the INMEGENfirst USD $\$ 65$ million in 2010 and then a second gift of USD \$75 million in 2013-Mexican business titan and philanthropist Carlos Slim Helú founded SIGMA, making reportedly the largest philanthropic gift on record within Latin America for scientific research (Toche and Lino 2014). In so doing, the Carlos Slim Foundation made the Eli and Edythe L. Broad Institute of MIT and Harvard (located in Cambridge, Massachusetts) the central node of a large-scale research venture, which would encompass INMEGEN, as well as Mexico's National Institute of Medical Science and Nutrition, other Mexican research centers, and additional US collaborators. As part of SIGMA's strategy, early-career scientists from INMEGEN and other Mexican institutions would travel to the Broad Institute for advanced training residencies, in addition to shorter visits to Mexico by Broad Institute investigators. Substantively, SIGMA leaders announced that the application of genomics to diabetes would be a central concern of the research "with a special focus on Latin American populations" (Broad Institute 2010).

The philanthropy's interest in this arena of high-tech and data-rich bioscience fit well with its broader portfolio. When the Foundation opened its health sector in 2007, the Bulletin of the World Health Organization, noted that "after reportedly surpassing Bill Gates as the world's richest man, Mexican telecommunications magnate Carlos Slim Helú is now charting a similar course to the Microsoft guru in the health field" (Braine 2007, 574). Like the Bill and Melinda Gates Foundation (and sometimes in partnership with it), the Foundation has supported health projects driven by technological innovation, frequently employing digital communication technologies in the design of initiatives aimed at improving health system management, personal health promotion, and healthcare provider training (Fundación Carlos Slim 2017; Coronel 2012).

To these initiatives, the Foundation brings perspective gained through Carlos Slim's experience in private enterprise, as Dr. Roberto Tapia-Conyer, who previously led the Foundation's health sector and now leads the organization as Director General, explained in an interview. "I can tell you that I have never met a more visionary man," Dr. Tapia-Conyer said. "He anticipates scenarios that you don't see yet, but he does and he, he was the one who started to ask us, what's going on with diabetes and genetics, who is the best out there in this area." The Foundation's approach to its investment in genomic science also reflected a time scale imported from the for-profit world. "We didn't want to invest in basic research to create basic knowledge, we wanted to be able to convert that knowledge immediately into policy action," Dr. TapiaConyer explained. Policy action, in this case, means also clinical impact, specifically via the development of novel diagnostic tools (Carlos Slim Helú 2013).

Indeed, the decision to make the Broad Institute the center of SIGMA's scientific activities largely reflected this desire for expediency. Dr. Tapia-Conyer explained that the decision to invest in the Broad Institute was about practicality. "There was a National Institute of Genomic 
Medicine [in Mexico], a great initiative, but it was just beginning its life, and we couldn't wait." Also linked to this goal for rapid translation, three years into the SIGMA initiative, the Foundation in partnership with private investors helped establish in Mexico a biotech firm to market these future technologies. Ultimately, in the Broad Institute, the Foundation's leaders perceived the capacity to rapidly produce actionable findings. For the venture, the Broad's involvement also signified the benefit of existing ties to other institutions in the United States.

The Broad "brought to the table," in the words of one its scientists, an existing relationship with investigators at the University of California Los Angeles where an on-going project, the Multi-Ethnic Cohort (MEC) study, had collected thousands of samples across four major, self-reported ethnic groups, including Latinos (both US born and immigrants from "Mexico, South or Central America"), also tracking outcomes like diabetes and cancer (The Sigma Type 2 Diabetes Consortium 2014b). In the end, the SIGMA database would draw on four cohort studies-three located in Mexico City and this Los Angeles-based study. Of the overall SIGMA sample of 8,214 participants, 4,199 would be drawn from MEC. This injection of thousands of existing samples from Los Angeles would not only statistically power SIGMA's analyses, but also make it possible for SIGMA to meet its initial 3-year goals in half the time, according to Dr. TapiaConyer. However, with the integration of MEC participants, a clear decision was made: Purely "Mexican" data was unnecessary. We return to this below.

In the years that followed, SIGMA's research and subsequent action to translate its findings into marketable technologies have dealt with diverse technoscientific objectspopulations, samples, genomic data, and risk scores. These objects have been variously and sometimes interchangeably categorized along distinct biosocial lines-as Mexican, Latin American, and Latino. Below we offer insight into the decentering of the Mexican genome and the use of these broader, panethnic identity categories in the context of this work. We also show how flexibility with respect to the particular genomic identities employed and ambiguity inherent in these categories have been integral to the creation and management of various forms of scientific and, later on, commercial value.

\section{Genomic Identity and the SIGMA Consortium}

Attention to the identities used in the practice of genomic science is worthwhile for several reasons. They indicate who participated in the research and to whom the findings might be generalized. In other words, when researchers discover a genetic variant associated with diabetes risk in their sample, these descriptors help communicate the scope of the broader population likely "at risk" for carrying it. These descriptors also help us to understand who should be screened for the variant and who not. Moreover, as we discussed above, identity categories used in the practice of genomic science validate scientifically understanding of human difference along their contours.

Here, we bring forth the factors that have facilitated the de-centering of the Mexican genome in the context of the SIGMA Type 2 Diabetes Consortium's scientific practice, even while Mexico's most important publicly-funded medical research institutes-including the 
INMEGEN-were key participants. This de-centering of the Mexican genome is most clearly visible through the SIGMA Consortium's scientific publications. We therefore focus on two peerreviewed papers published by the SIGMA Consortium in 2014, each of which describes the discovery of genetic variants associated with diabetes. These papers remain among the SIGMA Consortium's most significant publications and the findings they report have been foundational for continued research among consortium members and numerous subsequent publications.

The first of these initial papers was published in the journal Nature in February 2014, entitled "Sequence Variants in SLC16A11 are a Common Risk Factor for Type 2 Diabetes in Mexico" (The Sigma Type 2 Diabetes Consortium 2014b). The second was published four months later in the Journal of the American Medical Association (JAMA). It was titled, "Association of a Low-Frequency Variant in HNF1A with Type 2 Diabetes in a Latino Population" (The Sigma Type 2 Diabetes Consortium 2014a). Both papers analyzed pooled data drawn from the participants of the same four cohort studies mentioned above. However, they describe the populations to which their findings are relevant in different terms. The first reports a variant found in "Mexicans and other Latin Americans," while the second paper reports a variant found among "Latinos" - an identity category salient in the United States, with a rich political history there, but less commonly employed in Latin America (Roth 2009; Rumbaut 2009). Most importantly, neither paper suggests the variants were specific to Mexicans alone, nor do they invoke the idea of the Mexican Genome.

Were the different approaches to genomic identity taken in these papers imposed by journal editors? No, as one SIGMA investigator based at the Broad explained in an interview, while sharing excerpts from the initial reviews of the JAMA paper. On the contrary, editors worried that "calling someone Latino covers a lot of genetic subpopulations," he shared. The editors had pushed back on the authors' approach. To explain this shift and the decision to describe SIGMA's data as "Latino" in the second publication, we must look elsewhere.

First, we turn to SIGMA's sample and the four cohort studies from which the SIGMA database was drawn. These studies include the Los Angeles-based MEC Study, which expedited SIGMA's data collection efforts. "That is a cohort of Latinos. They were place of birth Mexico, South or Central America," noted a Mexico-based SIGMA member. "And you see in the plots that it's the most heterogenous population, probably because there are a lot of Cubans and Puerto Ricans and everything." She explained the MEC Study data not only expedited SIGMA's progress and, ultimately, statistically powered the sample, but the inclusion of the MEC data was valuable in a second sense-in terms of scientific impact. It increased the possibility of the study's reach and import beyond Mexico. A second Mexico-based SIGMA member echoed this point: "Toward the outside it will be more relevant if this can be extrapolated to Mexican Americans in the United States, rather than being just a finding in Mexico," she explained, adding:

In terms of how the information was presented we decided that the study could be extended to different Latin American populations, however, this has to be studied deeply... when the other groups [from the MEC Study cohort] were aggregated, the 
association remained and became a little bit stronger, yet we know that the main contribution to the finding is given by Mexican mestizos... and in the end it's how do you present this data in a way that is palatable, informative and valuable for the scientific community without it being so local.

Indeed, according to multiple consortium members we interviewed, SIGMA researchers firmly believed the variant they had identified was associated with their "Mexican" samples and that fully understanding their findings' relevance to "Latin Americans" would require continued study. Still, their findings were consistently communicated with emphasis on the region. A 2013 press release announced with regard to the Nature finding: "the elevated frequency of this risk gene in Latin Americans could account for as much as 20 percent of the populations' disproportionate prevalence of type 2 diabetes" (Broad Institute 2013).

In the JAMA paper published four months later, the category of "Latino" took center stage. The paper's abstract begins with a panethnic focus: "Latino populations have one of the highest prevalences of type 2 diabetes worldwide" (p. 2305). The authors continue, defining the paper's objectives: "To investigate the association between rare protein-coding genetic variants and prevalence of type 2 diabetes in a large Latino population and to explore potential molecular and physiological mechanisms for the observed relationships" (p. 2305, emphasis added). The body of the paper opens by translating the findings of the SIGMA Consortium's February paper in Nature into these panethnic terms-citing that paper, the authors write, "it was recently found that genetic variants in the gene SLC16A11 were associated with higher rates of type 2 diabetes in Latinos" (p. 2306). The authors add that "Latinos, defined as persons who trace their origin to Central and South America, and other Spanish cultures, fall on a continuum of Native American and European genetic ancestry" (p. 2306). In the following paragraphs, the authors describe the sample analyzed in the JAMA paper as a subset of the sample analyzed by the Nature study and clarify that this subset was chosen to capture individuals with particularly high percentages of "Native American ancestry" (p. 2306).

One of the authors of the JAMA paper, based at the Broad, reflected on resistance he perceived among some SIGMA investigators to the "Latino" category, especially among those originally from or based in Mexico. "We have a very strong identity of nationality in Mexico. We don't like to consider ourselves as Latinos or Latin Americans," he said. "We like to consider ourselves a completely separate entity." He added, "there is no doubt that this variant is coming from the Native American ancestry of the Mexican population. But we have to be very careful of how to say that because people in the media can immediately interpret this like if you are indigenous then you will develop type 2 diabetes." Scientists at SIGMA, he explained, were very aware of debates in the United States about race and the genome and they navigate these issues with care. He added that these concerns ultimately overrode the misfit of the "Latino" category in the eyes of some of the consortium's members. Another SIGMA investigator based at the Broad explained that personally he preferred the term "Latino" because it does not exclude individuals who were born in the United States, as the term "Latin Americans" might. "I think what we wanted to get away from is the idea that somehow there is a genetically distinct Mexican population" he added. "We can find genetic differences, but that doesn't mean that most of the 
risk for diabetes comes from Mexican- or Latino-type genes...I think that one thing we really wanted to convey is that genetic variation is mostly shared and that we are mostly the same."

Beyond these perspectives, the ability to move between the categories of "Mexicans and Latin Americans" and "Latinos" and, ultimately, to speak of individuals "of Native American ancestry" reflects flexibility within the categories themselves and suggests that the statistical processes to which the data in large omics studies are subjected for their harmonization warrants special attention. Data harmonization, in this case, is a statistical process carried out to homogenize or clean data from different sources so that it can be analyzed in the aggregate.

To understand, let us examine the February paper published in Nature. While the authors write that they analyzed data from 8,214 "Mexicans and other Latin Americans," over the course of the paper it becomes clear that they came to identify these individuals through a strictly statistical lens. That is, SIGMA Consortium researchers undertook the construction of a "statistical population," one separate from the lived identities of the individuals sampled, their geographic location, and their nationalities. To do this, each sample, whether from Mexico or Los Angeles, once sequenced, was submitted to a common procedure known as "Principal Component Analysis" to generate its unique ancestry profile (expressed as a percentage of Native American and European ancestry). This involved a bioinformatic assessment of each sample's statistical "proximity" to a set of three standard populations: Southern Europeans (Bask, French and Italians), Africans (Mandenka and Yoruba), and Native Americans from Mexico (Pima and Maya). According to the paper, the samples the SIGMA Consortium analyzed were deemed eligible for inclusion if their profiles fell appropriately "on a cline of Native American and European ancestry" (p. 97), with these two poles defined via comparisons to the "Bask, French and Italians" and "Pima and Maya" standards.

Notably, the process of data harmonization entails choices. First, one Mexico-based informant pointed out to us the elimination at this stage of any samples found to have high African or East Asian ancestry. This, she explained, was a matter of ensuring a more uniform ancestry across the sample. With regard to data on self-identified indigenous ancestry, samples from a cohort that were originally marked as "self-identified indigenous" were subjected to statistical analysis, and only those that exhibited statistical proximity to "Pima and Maya" samples were included in the study. When we inquired about this, our informant explained: "yes, the ancestral proportions actually measured were deemed more informative than the answer to the question 'Do you or your parents or grandparents speak/spoke an indigenous language?'” This provided grounds to trust data derived from this cohort's samples and integrate them. Data harmonization-selection, formatting, standardization, and classification-are part of what Leonelli (2016) has called "packaging procedures" that make data portable and comparable.

The Principal Component Analysis carried out for data harmonization also served to flatten the samples' nationalities and ties to political states, thus expanding their relevance and scope. Through this statistical process, samples take on a new identity inferred from the statistical behavior of their corresponding dot or "plot" on a data covariance matrix. Their identity became, in this case, a statistical function of their proximity to pre-defined social groups ("Bask, French and Italians" and "Pima and Maya"), no longer immediately aligned with any lived social 
identity. In publishing the findings of the study, SIGMA scientists (like all scientists engaging these procedures) had to translate these statistical identities back into a relevant social group. Who have they studied? To whom are their results applicable? Sometimes they translate differently, as is the case across the SIGMA Consortium's two initial publications. Standard definitions for the boundaries of the categories "Latinos" and "Latin Americans" are elusive, and so their inherent ambiguity was beneficial when faced with this task. These are open to interpretation-they can include Dominicans, Brazilians, and Argentineans, but they might also not. Although these categories are imprecise (a paradox in a field increasingly concerned with the project of "Precision Medicine"), their flexibility has value.

Ultimately, what we learn from the SIGMA publications is that the papers' approaches to genomic identity reflect adjustments made as diverse people, who self-identify in different ways, are brought together and harmonized in order to permit powerful statistical analyses of large datasets from different sources. Their approaches also reflect interest in expediency in this particular venture and the Broad Institute's "bringing to the table" a large dataset from California. Finally, our informants make clear that SIGMA investigators account for the impact of these categories in at least two ways: First, they worry how their results will be publicly perceived, and they select population categories to avoid fueling what they perceive could be socially problematic readings of their research. Second, SIGMA investigators valued the "relevance" or scientific impact of their findings beyond a single nation's boundaries.

Since these papers, SIGMA Consortium members (and others) working at the Broad and at key Mexican institutions have published numerous articles that draw on these findings and seek to extend them by, for example, clarifying the biological mechanisms by which each variant influences diabetes risk. Across this literature, movement between the categories of "Mexican," "Mexican Mestizos," "Latino," "Latin American," occasionally "Hispanic," and increasingly "Native American," is relatively fluid. In this sense, these genomic identities overlap and in many instances are interchangeable; "Mexican" rather seamlessly becomes "Latino" (and vice-versa).

\section{From Research to Technology: DIABETESprevent}

Carlos Slim's philanthropic donation to fund the SIGMA Consortium was also an investment. SIGMA Consortium members we interviewed widely acknowledged the gift came with a timeline and the understanding that SIGMA's research could be rapidly "translated" into marketable technologies appropriate for uptake on a national scale in the context of chronic disease health policymaking. "He's an entrepreneur," one SIGMA member observed, "He said okay I'm going to put this amount of money, but after three years I am going to get something out of it with potential commercial value." Another SIGMA member remarked: "It is an iconic project in the sense that it was financed by a private entity, a private business with private interests to create goods, services, develop knowledge, and they were not willing to wait."

As noted above, just as the Carlos Slim Foundation announced its second donation to the Broad Institute to fund SIGMA's second phase in 2013, it also helped to launch in Mexico City a small biotech startup, Patia Biopharma, to develop and market medical genomic technologies. 
The Foundation's Director, Dr. Roberto Tapia-Conyer, explained the intimate relationship between the philanthropy and the biotech firm in an interview. Patia Biopharma, he said, is a kind of experiment:

\begin{abstract}
It's an exercise, an initiative, something very innovative. To create a firm where investment, private investment, literally stockholders, are linked with social investment, literally a foundation. What you get is a business with a commercial, but also a social vision at the same time, where its earnings are just sufficient, just above cost, for its own sustainability. The philosophy stems from another history from within the group, a construction firm that Slim designed to undertake large-scale projects in Latin America with profit margins just above cost. That firm has been very successful, so successful that this small fraction above cost has meant profit.
\end{abstract}

It is difficult to think of Patia Biopharma as anything but a subsidiary of the philanthropy. A quick corporate genealogy furthers this point: In 2017 Patia Biopharma was primarily held by a venture capital fund owned by Grupo Financiero Inbursa (Banco Inbursa 2017), which is in turn a subsidiary of Grupo Carso, the umbrella conglomerate synonymous with Carlos Slim's corporate empire. Carlos Slim's son, Marco Antonio Slim Domit, serves as president of the board of directors of both Grupo Financiero Inbursa and the Carlos Slim Foundation, thereby presiding at the highest level of the conglomerate's philanthropic operations and venture capital investment in genomic medicine (Grupo Carso 2017; Instituto Carlos Slim de la Salud 2017).

In 2014, an early version of Patia Biopharma's website described its focus on the genomics of diabetes and cancer and its "commitment to close the gap between research and clinical implementation through the creation of preventive, diagnostic, and therapeutic tools within reach of the entire Mexican population, thus transforming health through 'preventive, personalized, and social' genomic medicine" (Patia Biopharma 2014). The company had already become the exclusive distributor in Mexico of Myriad Genetics' BRACAnalysis test that detects $B R C A 1$ and $B R C A 2$ gene mutations, which are linked to hereditary breast and ovarian cancer (Cruz Martínez 2013). But it was also developing its own genetic test, "designed specifically to evaluate type 2 diabetes risk in the Mexican population" (Patia Biopharma 2014). To do so, Patia Biopharma would leverage the advances being made by the SIGMA Consortium, specifically the research on SLC16A11 and HNF1A described above. By 2016 the genetic test, DIABETESprevent, was on the market.

Before the launch of DIABETESprevent, the Mexican public and medical community had received news about SIGMA's findings via press conferences and sponsored symposiums. Headlines atop news articles in Mexican media largely described these genetic variants as "Mexican," but typically clarified in the body of the article their relevance to "other Latin American populations," noting the studies had included participants from Los Angeles. However, headlines also broadly geneticized type 2 diabetes in Mexico as they announced SIGMA's findings. A headline in one of Mexico's leading newspapers, Milenio, in December 2013 following a SIGMA press conference, read "A gene predisposing Mexicans to type 2 diabetes has 
been found: Nature." Forbes México's headline similarly announced, "A gene is found that provokes type 2 diabetes in Mexicans." El Economista's headline remarked, "A 'thrifty gene'...is behind the diabetes epidemic." However, for those who read beyond the headlines, leading SIGMA scientists like Dr. María Teresa Tusié Luna also carefully acknowledged that while "arriving at diabetes by way of this gene is very frequent in Mexico, it's just a piece of the set of components that contribute to the development of the disease, that's why the second step is to understand better [SLC16A11's] function and, as we come to understand what activates it, what represses it, what are the effects of its expression, these findings could have a lot of impact on our capacity to prevent diabetes or on the possibility to treat patients more effectively" (Ruiz Jaimes 2014).

As Tusié Luna indicated, much was still be to be learned about the SLC16A11 and HNF1A variants SIGMA had discovered. Still, Patia Biopharma's representatives moved quickly to integrate them into a genetic test. Although it was available earlier online, in January 2017 the company held a press event in Mexico. Following the event, Milenio described DIABETESprevent in a feature article, affirming it was developed "especially for the Mexican population," (García Ramírez 2017). The Milenio article explains: "SLC6A11 is present in 30 percent of the Mexican population and is the main cause for the high incidence of this disease in the country. The HNF-1 variant is less present among Mexicans, but represents a higher risk." El Universal likewise affirmed the development of DIABETESprevent "especially for the Mexican population" (Miranda 2017). El Economista reported the same and quoted Patia's CEO, as follows: "Research began in 2010, with a first phase to identify the genetic variants in the Mexican population associated with the risk of suffering type 2 diabetes. From this, knowledge emerged about new variants associated with the disease, and what Patia did was turn this knowledge, together with another investigation, into a tool that allows for the analysis of multiple variants in a simple, fast, and massive way, and a very important factor, at a low cost" (Toche 2017). In the context of the test's marketing, SIGMA's study population was redefined once again-gone were references to "Latin Americans" and "Latinos." According to Patia Biopharma's statements to the press, DIABETESprevent was designed for Mexicans and had drawn on SIGMA's research "in the Mexican population."

Before the press event, Patia Biopharma representatives were already working to promote the uptake of DIABETESprevent within Mexico's national health system and had initiated a large-scale trial for its implementation (sponsored by the Carlos Slim Foundation) in the Mexican state of Puebla. This initiative would build the evidence base necessary to justify integration into the national health system (Betancourt 2018). In the meantime, DIABETESprevent was made available for purchase through select physicians and also online as a direct-to-consumer product. Valued at 1400 pesos on the international market, the Carlos Slim Foundation was subsidizing its sale in Mexico for 999 pesos at its launch (about US\$50). Patia's homepage was remade to feature the tagline "You Can Prevent Type 2 Diabetes-Discover your genetic predisposition and that of your family to type 2 diabetes with a simple test." Below this, an image of a smiling young family appeared-fit, fair-skinned parents with a blond-haired, blue-eyed child (a racialized marketing approach exceedingly common in Mexico)—suggesting 
that testing for diabetes genetic predisposition is a family affair and that it is intended for those who want to maintain their health.

The test itself involves a cheek swab to collect a DNA sample and a short questionnaire where users report their family history of diabetes and their ancestry. Users also report height and weight and sign a consent form in which they give Patia permission to use their data in future research. If taken at home, the sample is delivered and collected via courier service and then tested for 16 different genetic variants, including SCL16A11 and HNF1A-SIGMA's two discoveries. The test result is a "type 2 diabetes risk score" produced via an algorithm that accounts for the presence (or absence) of these variants and the user's ancestry (data about height and weight being reserved for the purposes of future research). The result is returned via your doctor or, if taken at home, directly to you via a smart-phone app. The app doubles as a health management portal where, going forward, customers are encouraged to input and track data about their health, diet, and exercise to assist them in managing their risk of developing the disease.

A few months after the press event in Mexico City, we observed a training session that Patia Biopharma sponsored for a group of young "promoters," mostly college students, who had been hired to stimulate sales of DIABETESprevent in Sanborns stores-a national chain of department stores owned, as well, by Carlos Slim-where they had been approaching customers to pitch the test. Preparing them to start promoting DIABETESprevent to patients in private medical clinics, a physician (contracted by Patia) carefully explained diabetes physiology to the young promoters and how best to pitch the test to patients in a medical setting. Here too, SLC16A11 was made distinctly Mexican-among the physician and the promoters it was referred to as "El Gen Mexicano de la Diabetes" — and the pitch to be communicated to patients for the test was similarly tied to Mexican identity at the level of the genome. The training ensued as follows:

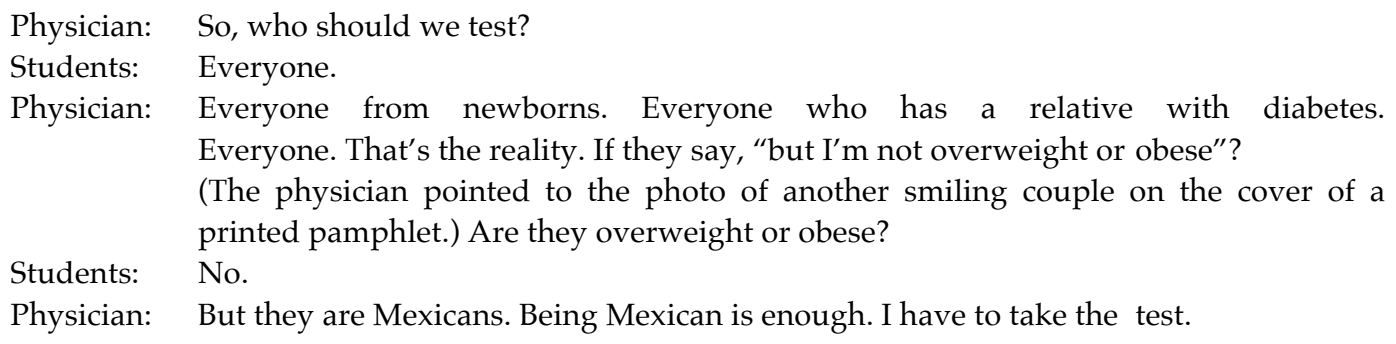

If this is how DIABETESPrevent was to be marketed, why did the Carlos Slim Foundation not limit the scope of the research it funded to Mexican participants? We asked this question of a Patia representative, who replied that this was "a commercial consideration." In her view, "Slim couldn't segment his market to that extent." As her answer suggests, within Mexico DIABETESprevent could be promoted as a technology developed especially for the Mexican population, but the test would not remain tied exclusively to Mexico. It was always intended for a larger market. Slim had long had "Latin America" in mind, she explained, but actually the plan for DIABETESprevent extended beyond the Americas. In 2015, Patia Europe was established in 
San Sebastian, Spain, with the goal to market DIABETESprevent on the European continent (Canal Diabetes 2016). ${ }^{.}$Meanwhile Patia representatives we interviewed have been working to open markets in other parts of Latin America and in the United States. In late 2017, at a luncheon hosted by Patia representatives at a Mexico City hospital, where they presented the prospects for DIABETESprevent moving forward, a keynote speaker explained that after "Latinos," the next frontier for DIABETESprevent would be the "Arab" world.

In interviews with Patia's medical director, she explained the company's genetic test is indeed designed for use globally. Both in Mexico and in Spain, she said, the test assesses the same 16 variants (some of which are, in fact, common in European populations and rare elsewhere). Adjustments are made to the algorithm that produces the risk score in order to account for ancestry. She explained: "If the sample comes from Spain and in the information about the person we read that the ancestors come from the Caribbean or from South Asia, it doesn't matter that the sample was collected in Spain, it wouldn't go through the European algorithm. It's not country specific, it's ethnic or ancestry specific." In this way, Patia accounts for the self-reported ancestry that users note on the form they fill-out and return with their cheek swab. (In contrast to the irrelevance of self-reported Native American ancestry in the process of SIGMA's research, here self-reported ancestry is useful data.)

On this form users are asked to check one of the following ancestry choices: Western Europe, Eastern/Central Europe, Southern Europe, Middle/Near East, South Asia, Latin America/Caribbean, Africa, Ashkenazi Jewish, Asia, or Other (beside which a space is provided where the user may write in another ancestry). Despite its relevance to the algorithm employed in Patia's analysis, the form does not include instructions to guide users as they fill out this section. In presentations we observed where Patia representatives introduced the test to physicians in Mexico City, guidance on how to deal with ambiguities in family histories and mixed-ancestries was likewise absent.

This also became an issue when one of this paper's co-authors (hereafter "EV") purchased DIABETESprevent online to learn her own risk score, which was categorized as "high" at 78\%. Her results were accompanied by the statement: "The genetic risk of this patient is high above the average genetic risk of the population." On a video-call with Patia's medical director, the result came under question when EV noted she had marked "Latin American" ancestry on the form. EV's father is Peruvian and her mother is of European descent, mostly English and German, as far as the family knows, she explained. "You labeled yourself as Latin American ethnicity. Then the population we are comparing you to is the Mexican population...If you don't mind, I would like to run these results again," the medical director said. "Considering also that you are of European ancestry." Evidently, EV's genome resisted a simple classificatory approach.

Following their video-call, the medical director re-processed EV's test using an algorithm tailored for European ancestry. On a subsequent call she shared the following:

${ }^{5}$ In Spain the marketing of DIABETESprevent contrasts with that in Mexico. Patia Europe's promotional videos, press releases, and media coverage typically lack reference to any particular population-the Mexican-ness of the test disappears as the technology moves abroad. 
When I run it through the more Mexican and American Indian algorithm, that gives you a [risk score of] 78. When I run it through the European algorithm, which is mostly Caucasian ancestry, then the frequencies are just a little bit different. You get a $69 \%$.

The medical director cautioned, however, that "the relative numbers change, 69 or 78 , but you continue to be in the high [risk] category." They discussed the meaning of this change in risk score-a number that is meant to indicate the likelihood of developing type 2 diabetes over one's lifetime. A risk score of around 70\%, the medical director explained, translates into about 1.7 times more chance of developing diabetes than the average across the population. However, she explained:

I try not to focus so much on the number and more on the perspective that what seems to me to be clear, for your genotype, certainly you have a genetic predisposition that is fairly high.

In this way, the medical director urged EV to focus on her genetic risk as low, vs. medium, vs. high - a ranking consistent, regardless of how her ancestry was analyzed. In the end, EV's ancestry had become less relevant to the equation.

As we track DIABETESprevent, moving from its marketing in Mexico as tailored to Mexicans, to the difficulties of self-reported ancestry, to the interpretation of a risk score, we are thus met with multiple instances of strategic ambiguity. These are not inaccuracies. They are the ambiguities that arise at the intersection of social identity and genetic data in transnational circulation - that is, as they move across national contexts with distinct racial regimes and ways of understanding human difference and belonging (Almaguer 2012). This is the flexibility on which genomic knowledge "tailored" to specific populations and genomic identities relies as it circulates worldwide.

\section{A New Regime of Value in Mexican Medical Genomics}

A decade after its instantiation in Mexican law, what is the value of the Mexican genome? In this paper, we have traced the trajectory of the Mexican genome since its mobilization in the early 2000s to garner support for public investment in genomic science in Mexico. We have pointed to the de-centering of this technoscientific entity with time, given the imperative for ever-larger scale and transnational collaboration. Private investment in this field-a goal among the original proponents of genomic medicine in Mexico-and the vision of philanthro-entrepreneurs have also meaningfully shaped how genomic identity has been conceived and communicated in Mexico over the last decade.

The trajectory of the Mexican genome that we have traced not only suggests there are significant limits to the value of National Genomes. Our case also points to the value of their alternative, namely broader transnationally relevant categories marked by flexibility and 
ambiguity." Categorical flexibility-the possibility to negotiate diverse influences on how a sample's identity is described by moving fluidly between categories-was an asset in the context of SIGMA's transnational practice. The related concept of categorical ambiguity-the withincategory imprecisions that render them broad and permit overlap-also emerged as a resource. Indeed, our case centers the value to medical genomics of Latino/Hispanic panethnicity's inherent nature as a "masterpiece of ambiguity" (Matute-Bianchi 1979, quoted in Oboler 2007, p. 119).

As Christina Mora (2014) has written, viewed historically the existence of Latino/Hispanic panethnicity in the United States and the institutionalization of these identity categories were far from inevitable. The more bureaucratic "Hispanic" and the originally more grass-roots "Latino" identities, she writes, were employed strategically to unify vastly different groups living in separate areas of the country. Mora (2014) writes: "Government officials, activists, and media executives never precisely defined who Hispanics actually were. Instead, they made broad, ambiguous references to the group's unifying culture and contended that Hispanics were Hispanic because they were all hardworking, religious, and family focused, characteristics that could have been applied to any group" (p. 5). The category's ambiguity "allowed stakeholders to bend the definition of Hispanic panethnicity and use the notion instrumentally—as a means to an end" (p. 5).

Our case demonstrates the continued utility of panethnicity's ambiguous nature, now as a scientific and commercial resource in the arena of medical genomics. Moreover, deployment of the "Latino" category in the transnational field we have explored offers insight into the dynamics of contemporary international circulation of this US-rooted category (Dávila 2001; Roth 2009), as well as the processes fostering identity and belonging beyond the limits of the nation in our contemporary world (Okamoto and Mora 2014). The role here of technoscience-specifically medical genomics-in the "Latino" category's continued formation and international expansion is particularly noteworthy, as scholars have more commonly traced the development and uptake of the Latino category in the US context through census practices, social movements and policymaking, and the domains of media and marketing (Mora 2014; Oboler 2007; Dávila 2001; Rodríguez 2000; Rumbaut 2009).

\footnotetext{
${ }^{6}$ In a key comparative example, Burton (2018) describes the case of a nationally-framed approach to genomic diversity that extends beyond the reach of the nation's territory. The Stanford-based Iranian-American genome project recreated the population categories and nationalist discourse of "unity in diversity" promoted by the Iranian state, through a phenomenon Burton calls "diasporic nationalism." Here, the category "Iranian" remains even if it is amended to include a more diversified group identity in the US context with new racial dimensions.

- This said, while signs of the biomedical expansion of the Latino category are evident (a recent PubMed search of genomics publications involving "Latino" and "Hispanic" categories yields a larger number of papers than those using "Mexican"), we must attend carefully to resistances to panethnicity among both experts and publics (Whitmarsh 2009). This remains a critical task with regard to biomedicine's increasing use of the category "Latino" in Latin America. Also, although science and medicine have not typically figured as a key domain for the "Latino" category's development, it is critical to note that scholars have widely implicated medicine and public health in shaping the broader meaning of the Latino category, especially its racialization, in the United States (for example Chavez 2008; Santiago-Irizarry 2001). This is
} 
Through our case we also add new dimensions to growing interest in science studies to the productive role of ambiguity in scientific practice. Panofsky and Bliss (2017) have observed that most science studies literature "interprets ambiguity, polyvocality, and underlying disagreement as a problem for science" (p. 62). Counterintuitively, Panofsky and Bliss (2017) have found that within human genetics ambiguity in taxonomies applied to human groups has increased dramatically in the published literature over recent decades. They write that "rationalization or standardization has not been the route to authority in this case, but rather dimensions of ambiguity in population classification have helped human geneticists build authority though coordinated activity, resisting oversight, and maintaining accountability to clients and participants" (p. 82), even as this reliance on ambiguity permits scientists to avoid grappling epistemologically with key complexities. Our case reflects these findings and, additionally, emphasizes the utility of ambiguity at the intersection of science and commercial action, as risk variants are translated into genetic tests intended for sale across global markets.

Finally, the de-centering over time of the Mexican genome that we have described has important implications for science policy internationally, where the pursuit of National Genomes has been widely promoted as a resource for both health and economic development, especially for developing nations. First, our case points to the kind of impact genomics might imply for health systems. The discovery of risk variants at the level of one's genome produces actionable information only through the consumption of diagnostic devices like DIABETESprevent. As Mitchell \& Waldby (2009) have written, "ontologizing risk opens up a market for diagnostic devices that will allow individuals to determine whether they are at risk for given conditions...ontologizing risk also makes it possible to expand considerably the market for preventive drugs: that is, drugs that aim not to cure or alleviate a current disease state but instead prevent a future instance of a disease for which one is 'at risk'" (p. 346-347). They add that this enables the expansion of pharmaceutical markets by closely aligning the maintenance of health with pharmaceutical interventions. In this way, we want to highlight that the pursuit of National Genomes stands to deepen the inscription of commercial mediation and market logic onto the social contract between states, populations, and future health through the increased necessity of medical diagnostics and, potentially, pharmaceuticals. While medical genomic initiatives like SIGMA may indeed make the advances of genomic medicine available to people in settings like Mexico, it is important to recognize that their "inclusion" will likely be, for this reason, as consumers.

Finally, with regard to the potential of National Genomes to bring developing nations into the global bioeconomy and bolster their economic development, our case is likewise instructive. The legal framework underpinning Mexico's 2008 genomic sovereignty policy, documented in official congressional records, recognized the obligation of the Mexican state to provide citizens access to the health services that would be derived from knowledge about the genomic structure of the Mexican people, but it also explicitly stated that this must be done "without discouraging the generation of new goods and businesses based on the development of

also true of the related categories of "Mexican" and "Mexican-American" in the United States (see especially Montoya 2011; Molina 2014; Stern 2005). 
this new technology" (Cámara de Diputados, 2008, p. 8). Its designers did not intend that genomic medicine in Mexico would remain a primarily publicly-funded project. To an extent, with Carlos Slim's involvement in Mexican medical genomics, both philanthropically and commercially, this goal was advanced. But Carlos Slim's investments also serve to temper earlier fantasies about what building a genomics-based economic sector might mean for a country like Mexico. In practice, this appears to represent if anything, so far, the continued concentration of "wealth as usual," offering a path for the country's most powerful entrepreneur's deeper incursions into the healthcare sector.

\section{Conclusion}

Although it continues to circulate in scientific analyses and literature, the fate of the Mexican genome is uncertain and the vision of genomic sovereignty as a radical, empowering, and deeply nationalist "postcolonial" approach to science policy (Benjamin 2009) has become increasingly unsustainable in Mexico with time. To the extent that this policy approach aimed to foster a transition-a shift from a publicly-funded scientific field to a privately-driven economic sectorthe eventual de-centering of the Mexican genome now seems almost inevitable. The scientific imperative for "big data" and the inevitable commercial demand for "bigger markets" fundamentally limit the utility of nationally-bound genomic identities. Under the present conditions that mark the field of medical genomics-where transnational and public-private collaboration are common-we argue that broad, flexible categories of genomic identity are far more likely to accompany the travels of data from national projects to international consortia, where they are pooled in scientific databases, and finally incorporated into commercial technologies.

\section{Author Biography}

Emily Vasquez is a doctoral candidate in the Departments of Sociomedical Sciences and Sociology at Columbia University and a Mellon/ ACLS Dissertation Completion Fellow. An ethnographer of health, science and medicine, her research explores relationships between health and justice, knowledge and power, and race and nation in Latin America.

\section{Author Biography}

Vivette García-Deister is Associate Professor at the National Autonomous University of Mexico, where she is co-responsible for the STS laboratory at the School of Sciences. Her research focuses on the history of race science, the epistemologies of biomedical and forensic genetics in Mexico, and the philosophy of science in practice, as informed by ethnographic methods and critical anthropology of science. She studies the impact of biomedical and forensic genetics on issues of health, racism and justice. 


\section{Acknowledgements}

This research was supported by the National Science Foundation, Science, Technology and Society Division (Grant: SES- 1656224) and by PAPIIT- DGAPA- UNAM Grant IA401416. We extend thanks to Alondra Nelson, Jenny Reardon, and Katie Vann for their comments on this paper, as well as an anonymous referee. We are also grateful for the participation of the scientists and health professionals who discussed their work with us for the purpose of this research.

\section{References}

Abu El-Haj, Nadia. 2007. "The Genetic Reinscription of Race." Annual Review of Anthropology 36 (1):283-300. doi: 10.1146/ annurev.anthro.34.081804.120522.

Almaguer, Tomás. 2012. "Race, Racialization, and Latino Populations in the United States." In Racial formation in the twenty-first century, edited by Daniel Martinez HoSang, Oneka LaBennett and Laura Pulido, 143-161. Berkeley: University of California Press.

Appadurai, Arjun. 1986. The Social life of things: Commodities in cultural perspective. Edited by Arjun Appadurai. Cambridge: Cambridge University Press.

Banco Inbursa. 2017. Banco Inbursa Informa sus Resultados Correspondientes al Segundo Trimestre de 2017 [Banco Inbursa Announces its Results Cooresponding to the Second Trimester of 2017]. Mexico City.

Benjamin, Ruha. 2009. "A Lab of Their Own: Genomic sovereignty as postcolonial science policy." Policy and Society 28 (4):341-355. doi: 10.1016/j.polsoc.2009.09.007.

Betancourt, Miguel. 2018. "Genómica y Enfermedades Crónicas." Primera Sesión Académica de la Maestría en Salud Pública, Universidad Popular Autónoma del Estado de Puebla, Puebla, México.

Birch, Kean, and David Tyfield. 2012. "Theorizing the Bioeconomy." Science, Technology, \& Human Values 38 (3):299-327. doi: 10.1177/0162243912442398.

Bliss, Catherine. 2012. Race decoded: The genomic fight for social justice. Stanford, California: Stanford University Press.

Bliss, Catherine. 2013. "The Marketization of Identity Politics." Sociology 47 (5):1011-1025. doi: $10.1177 / 0038038513495604$.

Braine, Theresa. 2007. "Mexican billionaire invests millions in Latin American health." Bulletin of the World Health Organization 85:574-575.

Broad Institute. $2010 . \quad$ "Mexico-US Collaboration Launched." https: / / www.broadinstitute.org/news/mexico-us-collaboration-launched.

Broad Institute. 2013. "New Genetic Risk Factor for Type 2 Diabetes Revealed." accessed October 1, 2017. https:/ / www.broadinstitute.org/news/new-genetic-risk-factor-type-2-diabetesrevealed.

Burton, Elise K. 2018. "Narrating ethnicity and diversity in Middle Eastern national genome projects." Social Studies of Science 48 (5):762-786. doi: 10.1177/ 0306312718804888. 
Busby, Helen, and Paul Martin. 2006. "Biobanks, national identity and imagined communities: The case of UK biobank." Science as Culture 15 (3):237-251. doi: $10.1080 / 09505430600890693$.

Cámara de Diputados. 2008. "Proceso Legislativo - Decreto por el que se reforma la fracción V del artículo 100 y el artículo 461, y se adicionan los artículos 317 Bis y 317 Bis 1, todos de la Ley General de Salud." Diario Oficial de la Federación. http:/ / www.diputados.gob.mx/LeyesBiblio/proceso/1x/101_DOF_14jul08.pdf.

Canal Diabetes. 2016. "Diabetes Prevent ayuda a conocer el riesgo de diabetes tipo 2." accessed 15 October 2017. http:/ / www.canaldiabetes.com/diabetes-prevent/.

Carlos Slim Helú. 2013. "Mexico-US Genomics Partnership Launches Second Phase." accessed October 152017. http://www.carlosslim.com/responsabilidad_slim_medicina_genomica_ing.html.

Chavez, Leo R. 2008. The Latino threat: Constructing immigrants, citizens, and the nation. Stanford: Stanford University Press.

Coronel, Maribel R. 2012. Los Pasos de Slim en la Salud. El Economista. Accessed 15 April 2012.

Cruz Martínez, Ángeles. 2013. "Informan sobre prueba específica de predisposición a cáncer de mama." La Lornada, $25 \quad$ September $2013, \quad 38$. http:/ / www.jornada.unam.mx/2013/09/25/sociedad/038n3soc.

Cullell, Jon Martín. 2019. ¿Existe el ‘ADN mexicano'? El Pais. https://verne.elpais.com/verne/2019/01/19/mexico/1547866590_722415.html

Dávila, Arlene M. 2001. Latinos, Inc.: The marketing and making of a people. Berkeley: University of California Press.

de Vries, Jantina, Melodie Slabbert, and Michael S. Pepper. 2012. "Ethical, legal and social issues in the context of the planning stages of the Southern African Human Genome Programme." Medicine and law 31 (1):119-152.

Duster, Troy. 2005. "Race and Reification in Science." Science 307 (5712):1050-1051. doi: $10.2307 / 3840144$.

Duster, Troy. 2015. "A post-genomic surprise. The molecular reinscription of race in science, law and medicine." The British Journal of Sociology 66 (1):1-27. doi: 10.1111/1468-4446.12118.

Ecks, Stefan. 2005. "Pharmaceutical Citizenship: Antidepressant Marketing and the Promise of Demarginalization in India." Anthropology \& Medicine 12 (3):239-254. doi: $10.1080 / 13648470500291360$.

Epstein, Steven. 2009. Inclusion: The politics of difference in medical research. Chicago: University of Chicago Press.

Fortun, Michael. 2008. Promising genomics: Iceland and deCODE Genetics in a world of speculation. Berkeley: University of California Press.

Fujimura, Joan H., and R. Rajagopalan. 2011. "Different differences: the use of 'genetic ancestry' versus race in biomedical human genetic research." Soc Stud Sci 41 (1):5-30.

Fullwiley, Duana. 2007. "Race and Genetics: Attempts to Define the Relationship." BioSocieties 2 (2):221-237. doi: 10.1017/S1745855207005625. 
Fullwiley, Duana. 2008. "The Biologistical Construction of Race: 'Admixture' Technology and the New Genetic Medicine." Social Studies of Science 38 (5):695-735. doi: 10.2307/25474605.

Fundación Carlos Slim. 2017. "Informe Annual." http://fundacion.eidos1.netdna-cdn.com/wpcontent/uploads/2017/01/informe-resultados.pdf.

García Ramírez, Mónica. 2017. "Crean primera prueba que detecta diabetes en el ADN." Milenio, 26 January 2017. Accessed $15 \quad$ October 2017. http:/ / www.milenio.com/cultura/primera_prueba_diabetes-adn-incmnszexpertos_mexicanos-celulas_epiteliales-milenio_0_891510852.html.

García-Deister, Vivette. 2014. "Laboratory Life of the Mexican Mestizo." In Mestizo Genomics: Race Mixture, Nation, and Science in Latin America, edited by Peter Wade, Carlos López-Beltrán, Eduardo Restrepo and Ricardo Ventura-Santos, 161-182. Durham, NC: Duke University Press.

Grupo Carso. 2017. "Consejo de Administración." accessed 15 October 2017. http:// www.carso.com.mx/ES/gobierno-corporativo/Paginas/ consejo-deadministracion.aspx.

Hardy, Billie-Jo, Beatrice Séguin, Federico Goodsaid, Gerardo Jimenez-Sanchez, Peter A. Singer, and Abdallah S. Daar. 2008. "The next steps for genomic medicine: challenges and opportunities for the developing world." Nat Rev Genet 9 (1):S23-S27.

Hinterberger, Amy, and Natalie Porter. 2015. "Genomic and Viral Sovereignty: Tethering the Materials of Global Biomedicine." Public Culture 27 (2 76):361-386. doi: 10.1215/089923632841904.

Hunt, Linda M., and Mary S. Megyesi. 2008. "The ambiguous meanings of the racial/ethnic categories routinely used in human genetics research." Social science $\mathcal{E}$ medicine (1982) 66 (2):349-361. doi: 10.1016/j.socscimed.2007.08.034.

Instituto Carlos Slim de la Salud. 2017. "Consejo Directivo." accessed 15 October 2017. http:/ / www.salud.carlosslim.org/ consejo-directivo/.

Jiménez Sanchez, Gerardo. 2002. "Oportunidades para la industria farmacéutica en el Instituto de Medicina Genómica de México." Gaceta Médica de México 138 (3):291-294.

Jiménez Sanchez, Gerardo. 2003a. "Developing a Platform for Genomic Medicine in Mexico." Science 300 (5617):295-296. doi: 10.2307/3834142.

Jiménez Sanchez, Gerardo. 2003b. "La medicina genómica como un instrumento estratégico en el desarrollo de México." Ciencia y Desarrollo 29 (172):33-35.

Jiménez Sanchez, Gerardo, Irma Silva-Zolezzi, Alfredo Hidalgo, and Santiago March. 2008. "Genomic medicine in Mexico: Initial steps and the road ahead." Genome Research 18 (8):1191-1198. doi: 10.1101/gr.065359.107.

Kahn, Jonathan. 2013. Race in a bottle: The story of BiDil and racialized medicine in a post-genomic age. New York: Columbia University Press.

Kent, Michael, Vivette García-Deister, Carlos López-Beltrán, Ricardo Ventura Santos, Ernesto Schwartz-Marín, and Peter Wade. 2015. "Building the genomic nation: 'Homo Brasilis' and the 'Genoma Mexicano' in comparative cultural perspective." Social Studies of Science 45 (6):839-861. doi: 10.1177/ 0306312715611262. 
Koenig, Barbara A., Sandra Soo-Jin Lee, and Sarah S. Richardson, eds. 2008. Revisiting race in a genomic age. New Brunswick, N.J.: Rutgers University Press.

Leonelli, Sabina. 2016. Data-centric biology: A philosophical study. Chicago: The University of Chicago Press.

Liu, Jennifer A. 2010. "Maing Taiwanese (Stem Cells): Identity, Genetics, and Hybridity." In Asian biotech: Ethics and communities of fate, edited by Aihwa Ong and Nancy N. Chen, 239-262. Durham, N.C.: Duke University Press.

Lopez-Beltran, Carlos, and Vivette García-Deister. 2013. "Scientific approaches to the Mexican mestizo." Hist Cienc Saude Manguinhos 20 (2):391-410.

López-Beltrán, Carlos, Vivette García-Deister, and Mariana Rios-Sandoval. 2014. "Negotiating the Mexican Mestizo: On the Possibility of a National Genomics." In Mestizo Genomics: Race Mixture, Nation, and Science in Latin America, edited by Peter Wade, Carlos López-Beltrán, Eduardo Restrepo and Ricardo Ventura-Santos, 85-106. Durham, NC: Duke University Press.

M'charek, Amade. 2005. The Human Genome Diversity Project: An ethnography of scientific practice. Cambridge: Cambridge University Press.

Miranda, Perla. 2017. "Lanzan prueba ue evalúa riesgo de diabetes." El Universal, 26 January 2017. $\begin{array}{llll}\text { Accessed } & 15 & \text { Octubre } & \end{array}$ http:/ / www.eluniversal.com.mx/articulo/nacion/seguridad/2017/01/26/lanzanprueba-que-evalua-riesgo-de-diabetes.

Mitchell, Robert, and Catherine Waldby. 2009. "National Biobanks: Clinical Labor, Risk Production, and the Creation of Biovalue." Science, Technology, \& Human Values 35 (3):330-355. doi: 10.1177 / 0162243909340267.

Molina, Natalia. 2014. How race is made in America: Immigration, citizenship, and the historical power of racial scripts. Berkeley: University of California Press.

Montoya, Michael J. 2011. Making the Mexican diabetic: Race, science, and the genetics of inequality. Berkley: University of California Press.

Mora, G. Cristina. 2014. Making Hispanics: How activists, bureaucrats, and media constructed a new American. Chicago: University of Chicago Press.

Oboler, Suzanne. 2007. "Citizenship and Belonging: The Construction of US Latino Identity Today." Iberoamericana (2001-) 7 (25):115-127.

OECD. 2009. " The bioeconomy to 2030: Designing a policy agenda." https: / / www.oecd.org/futures/long-termtechnologicalsocietalchallenges / 42837897.pdf.

Okamoto, Dina, and G. Cristina Mora. 2014. "Panethnicity." Annual Review of Sociology 40 (1):219239. doi: 10.1146 / annurev-soc-071913-043201.

Pálsson, Gísli, and Paul Rabinow. 1999. "Iceland: The Case of a National Human Genome Project." Anthropology Today 15 (5):14-18. doi: 10.2307/2678370.

Panofsky, Aaron, and Catherine Bliss. 2017. "Ambiguity and Scientific Authority: Population Classification in Genomic Science." American Sociological Review 82 (1):59-87. doi: $10.1177 / 0003122416685812$. 
Patia Biopharma. 2014. "Desarrollo propio de Patia Biopharma: DIABETESPredict." accessed 15 March 2014. http:/ / www.patia.com.mx/ diabetes.html.

Petersen, Alan, and Ivan Krisjansen. 2015. "Assembling 'the bioeconomy': Exploiting the power of the promissory life sciences." Journal of Sociology 51 (1):28-46. doi: $10.1177 / 1440783314562314$.

Pollock, Anne. 2012. Medicating race: Heart disease and durable preoccupations with difference. Durham: Duke University Press.

Rabinow, Paul. 1999. French DNA: Trouble in purgatory. Chicago, IL: University of Chicago Press.

Reardon, Jenny. 2005. Race to the finish: Identity and governance in an age of genomics. Princeton: Princeton University Press.

Reardon, Jenny. 2017. The postgenomic condition: Ethics, justice, and knowledge after the genome. Chicago: The University of Chicago Press.

Roberts, Dorothy. 2011. Fatal invention: How science, politics, and big business re-create race in the twenty-first century. New York: New Press.

Rodríguez, Clara E. 2000. Changing race: Latinos, the census, and the history of ethnicity in the United States. New York: New York University Press.

Roth, Wendy D. 2009. "'Latino before the world': The transnational extension of panethnicity." Ethnic and Racial Studies 32 (6):927-947. doi: 10.1080/01419870802245042.

Ruiz Jaimes, Elizabeth. 2014. Un "gen ahorrador" neandertal, detrás de la epidemia diabética. El Economista. Accessed October 12017.

Rumbaut, Rubén G. 2009. "Pigments of Our Imagination: On the Racialization and Racial Identities of "Hispanics" and "Latinos"." In How the United States racializes Latinos: White hegemony and its consequences, edited by José A. Cobas, Jorge Duany and Joe R. Feagin, 1536. Boulder: Paradigm.

Santiago-Irizarry, Vilma. 2001. Medicalizing ethnicity: The construction of Latino identity in a psychiatric setting. Ithaca, N.Y.: Cornell University Press.

Schwartz-Marín, Ernesto, and Alberto Arellano Méndez. 2012. "The law of genomic sovereignty and the protection of "Mexican genetic patrimony"." Medicine and law 31 (2):283-294.

Secretaría de Gobernación. 2008. "Decreto por el que se reforma la fracción V del artículo 100 y el artículo 461, y se adicionan los artículos 317 Bis y 317 Bis 1, todos de la Ley General de Salud." Diario Oficial de la Federación. http:/ / www.dof.gob.mx/nota_detalle.php?codigo=5053006\&fecha=14/07/2008.

Séguin, Beatrice, and BIllie-Jo Hardy. 2008. "Genomic medicine and developing countries: creating a room of their own." Nature reviews. Genetics 9 (6):487-493. doi: $10.1038 / \operatorname{nrg} 2379$.

Séguin, Beatrice, Billie-Jo Hardy, Peter A. Singer, and Abdallah S. Daar. 2008. "Genomics, public health and developing countries: the case of the Mexican National Institute of Genomic Medicine (INMEGEN)." Nature reviews. Genetics 9:S5-S9. doi: 10.1038/nrg2442.

Serrano-Perez-Grovas, A., J. C. Valdes-Olmedo, G. Soberon, and J. P. Laclette. 2001. "Development of the first Center for Genomic Medicine in Mexico." American journal of human genetics 69 (4):460. 
Silva-Zolezzi, Irma, Alfredo Hidalgo-Miranda, Jesus Estrada-Gil, Juan Carlos Fernandez-Lopez, Laura Uribe-Figueroa, Alejandra Contreras, Eros Balam-Ortiz, Laura del Bosque-Plata, David Velazquez-Fernandez, Cesar Lara, Rodrigo Goya, Enrique Hernandez-Lemus, Carlos Davila, Eduardo Barrientos, Santiago March, and Gerardo Jimenez-Sanchez. 2009. "Analysis of genomic diversity in Mexican Mestizo populations to develop genomic medicine in Mexico." Proceedings of the National Academy of Sciences 106 (21):8611-8616. doi: 10.1073 / pnas.0903045106.

Slabbert, M. Nöthling, and M. S. Pepper. 2010. "'A room of our own?' Legal lacunae regarding genomic sovereignty in South Africa." Tydskrif vir hedendaagse romeins-hollandse reg 73 (3):432-450.

Soo-Jin Lee, Sandra. 2005. "Racializing drug design: Implications if pharmacogenomics for health disparities." American journal of public health (1971) 95 (12):2133-2138.

Soo-Jin Lee, Sandra, Joanna Mountain, Barbara Koenig, Russ Altman, Melissa Brown, Albert Camarillo, Luca Cavalli-Sforza, Mildred Cho, Jennifer Eberhardt, Marcus Feldman, Richard Ford, Henry Greely, Roy King, Hazel Markus, Debra Satz, Matthew Snipp, Claude Steele, and Peter Underhill. 2008. "The ethics of characterizing difference: Guiding principles on using racial categories in human genetics." Genome Biology 9 (7):404. doi: 10.1186/gb-2008-9-7-404.

Stern, Alexandra. 2003. "From mestizophilia to biotypology: Racialization and science in Mexico." In Race $\mathcal{E}$ nation in modern Latin America, edited by Nancy P. Appelbaum, Anne S. Macpherson and Karin Alejandra Rosemblatt, 187-210. Chapel Hill: University of North Carolina Press.

Stern, Alexandra. 2005. Eugenic nation: Faults and frontiers of better breeding in modern America. Berkeley: University of California Press.

Sung, Wen-Ching. 2010. "Chinese DNA: Genomics and bionation." In Asian biotech: Ethics and communities of fate, edited by Aihwa Ong and Nancy N. Chen, 263-292. Durham, N.C.: Duke University Press.

Tekola-Ayele, F., and C. N. Rotimi. 2015. "Translational Genomics in Low- and Middle-Income Countries: Opportunities and Challenges." Public Health Genomics 18 (4):242-247.

The Sigma Type 2 Diabetes Consortium. 2014a. "Association of a low-frequency variant in HNF1A with type 2 diabetes in a latino population." JAMA 311 (22):2305-2314. doi: 10.1001 / jama.2014.6511.

The Sigma Type 2 Diabetes Consortium. 2014b. "Sequence variants in SLC16A11 are a common risk factor for type 2 diabetes in Mexico." Nature 506 (7486):97-101. doi: 10.1038 / nature12828.

Toche, Nelly. 2017. "Prueba genómica para evaluar diabetes." El Economista, 26 January 2017. Accessed 15 October 2017. https://www.eleconomista.com.mx/arteseideas/Pruebagenomica-para-evaluar-diabetes-20170126-0075.html.

Toche, Nelly, and Manuel Lino. 2014. "Localizan con genómica forma curable de diabetes." El Economista. http://aniversario.jornada.com.mx/ultimas/2013/12/26/descubre-sigmanuevo-gen-que-contribuye-a-incrementar-el-riesgo-de-desarrollar-diabetes-6996.html. 
Tupasela, Aaro. 2017. "Populations as brands in medical research: placing genes on the global genetic atlas." BioSocieties 12 (1):47-65. doi: 10.1057/s41292-016-0029-9.

Tutton, Richard. 2008. "Biobanks and the biopolitics of inclusion and representation." In Monitoring bodies: The new politics of biobanks, edited by H. Gottweis and A. Peterson, 159176. London: Routledge.

Vanguardia. 2019. "Aeroméxico trolea a estadounidenses y se desata la polémica." https: / / vanguardia.com.mx/articulo/aeromexico-trolea-estadounidenses-y-se-desatala-polemica.

Vasquez, Emily E., and Vivette García-Deister. 2019. "In pursuit of genomic justice: Sovereignty, inclusion, and innovation in Mexico." In Routledge Handbook on the Politics of Global Health, edited by Richard G. Parker and Jonathan García, 421-432. London and New York: Routledge.

Ventura Santos, Ricardo, Michael Kent, and Verlan Valle Gaspar Neto. 2014. "From Degeneration to Meeting Point: Historical Views on Race, Mixture, and the Biological Diversity of the Brazilian Population." In Mestizo Genomics: Race Mixture, Nation, and Science in Latin America, edited by Peter Wade, Carlos López Beltrán, Eduardo Restrepo and Ricardo Ventura Santos, 33-54. Durham, NC: Duke University Press.

Wade, Peter, Vivette García-Deister, Michael Kent, María Fernanda Olarte-Sierra, and Adriana Díaz del Castillo Hernández. 2014. "Nation and the Absent Presence of Race in Latin American Genomics." Current Anthropology 55 (5):497-522. doi: 10.1086/ 677945.

Wailoo, Keith, Alondra Nelson, and Catherine Lee, eds. 2012. Genetics and the unsettled past: The collision of DNA, race, and history. New Brunswick, NJ: Rutgers University Press.

Whitmarsh, Ian. 2008. Biomedical ambiguity race, asthma, and the contested meaning of genetic research in the Caribbean. Ithaca: Cornell University Press.

Whitmarsh, Ian. 2009. "Hyperdiagnostics: Postcolonial Utopics of Race-Based Biomedicine." Medical Anthropology 28 (3):285-315. doi: 10.1080/01459740903073554.

WHO. 2015. "WHO definitions of genetics and genomics." http:/ / www.who.int/genomics/geneticsVSgenomics/en/. 